\title{
WORKERLESS EPIMYRMA KRAUSSEI EMERY 1915, THE FIRST PARASITIC ANT OF CRETE.*
}

\section{By Alfred Buschinger}

Institut für Zoologie, Fachbereich Biologie, der Technischen Hochschule, D 6100 Darmstadt. Federal Republic of Germany

In the Mediterranean island of Crete (Greece), about 40 species of ants have been recorded until recently (Legakis 1987). A list kindly provided by A. Legakis in April, 1988, comprises a total of 45 species and subspecies, but does not include any socially parasitic taxon. Epixenus biroi Forel 1910, described from Crete and once believed to represent a parasite of Monomorium creticum Emery 1895 , is the intermorphic ("ergatoid") queen of this species. The genus Epixenus was synonymized with Monomorium by Brown and Wilson (1957). Tohmé and Tohmé (1979), however, apparently being unaware of the papers of Brown and Wilson (1957) and Ettershank (1966), retained the genus name Epixenus and described several new species, but emphasized that all of them are independent ants, as already stated by Bernard (1955) for Epixenus algiricus.

During a vacation stay in the island in April, 1988, I collected some ants, among them the "degenerate slavemaker", Epimyrma kraussei (Buschinger et al. 1986), which thus represents the first social parasite recorded for Crete. In addition, a colony of the slavemaking ant, Strongylognathus cf. insularis Baroni Urbani 1968 was found, on which I shall report in a separate paper. Eight colonies of Epimyrma kraussei were collected and kept in laboratory culture during the summer and fall, 1988. Seven of them produced Epimyrma sexuals.

Table 1 lists the collecting sites and data, as well as the offspring produced in the colonies. The nests were situated in dry walls built of a marly sandstone (no. 1-6), or in crevices of limestone rock (no. $7,8)$. Colonies were aspirated completely, and transferred to Germany in PVC-tubes as described by Buschinger and Heinze (1988). For laboratory rearing see methods in Buschinger et al. (1986).

The host species was identified as Leptothorax (Temnothorax) recedens (Nylander 1856), the usual host species of E. kraussei.

*Manuscript received by the editor April 7, 1989. 
Some host workers correspond to L. rogeri Emery 1869, having a more rounded, dome-like petiolar node as compared to "typical" $L$. recedens, where the node is sharply angulate in profile (Agosti and Collingwood 1987). However, in a direct comparison of material from Morocco, Spain, France, and southern Greece, I found so much intrapopulation and even intranidal variation in these characters that I question the validity of $L$. rogeri as a separate species.

Several E. kraussei colonies from Crete contained more than one Epimyrma female (Table 1). Since in this species the sexuals mate inside the mother nests, and the young queens remain there over winter (Buschinger et al. 1986), the females presumably were a queen and part of her offspring in several instances. Other young queens apparently had already left their mother nests and had begun to invade host colonies during the time of collecting. This is indicated by the fact that (1) only a few females were found in multiplefemale nests, and that (2) an Epimyrma queen in each of colonies 1 and 6 was just engaged in throttling a Leptothorax queen, as is usual in the genus during the parasitic colony foundation.

It is remarkable, therefore, that in the apparently newly infested colonies (no. 1 and 6) three females of Epimyrma were found in one of these colonies and two in the other. A multiple infestation by three parasitic females may also have occurred in colony 2 , in which two Epimyrma females were dead in the field, the third one dying soon after being collected. Only Leptothorax sexuals were reared from the hibernated brood of this colony. Thus, it is improbable that it had been infested already in the foregoing year, the three Epimyrma being a queen and two of her daughters. A host species queen, however, was not found in this nest.

Except for Epimyrma algeriana, which is facultatively polygynous (Buschinger et al. 1989), all species of this genus and all populations of $E$. kraussei are monogynous. Multiple infestations have been seen only rarely in E. corsica (Buschinger and Winter 1985). During laboratory culture in all E. kraussei colonies from Crete, the number of females dropped to one within the first 2-4 weeks, long before the new Epimyrma brood was reared. No fighting between females was seen; the supernumerary specimens just left the nests, wandering around in the formicaries until they eventually died. The population of Crete, therefore, is apparently monogynous as well, and I suspect that the multiple infestations occurred due to rarity of suitable host colonies. 


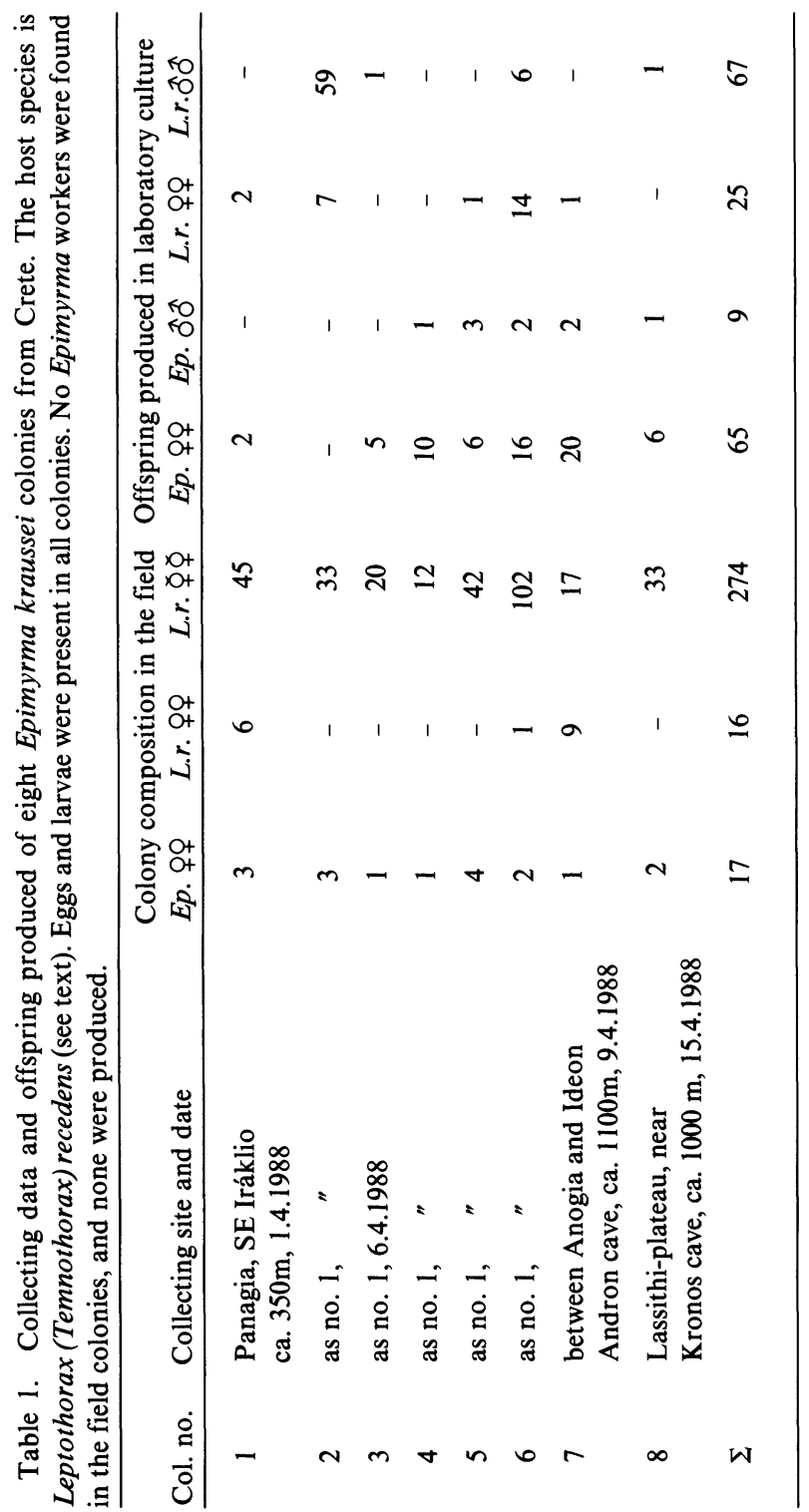


Another unusual character of the sample from Crete is the presence of several females of the host species in two of the Epimyrma colonies (no. 1 and 9), and the production of Leptothorax sexuals simultaneously with Epimyrma offspring in colonies 1, 5, 6 and 7 . Colony 1 , as was indicated above, had apparently been infested quite recently. The queen of the (monogynous) $L$. recedens colony was being throttled by one of the Epimyrma females, and the remaining five host females were not inseminated. The nine Leptothorax females of colony 7 also were virgins, and very probably all of them had remained in the nests and had shed their wings, since they had been unable to fly off because of bad weather during the swarming period. This is quite a common feature in Leptothorax.

The production of sexuals of host species in Epimyrma colonies is unusual, however, as is the absence of host worker production from hibernated brood (Table 1). In other Epimyrma populations and species the parasitic queens apparently inhibit the formation of host species females, and often they redirect the development of large larvae to become large workers or intermorphs. Male brood is usually destroyed, and in colony 4 the $E$. kraussei queen was observed biting and cutting up some Leptothorax male pupae. In other colonies, however, a few males of the host species emerged. Most remarkable is the fact that no Epimyrma workers were found in the field colonies, and none were produced in laboratory culture. With respect to worker numbers the genus exhibits an evolutionary transition from slave-making species having a reasonable workforce (E. ravouxi, E. stumperi, E. algeriana) to workerless species ( $E$. adlerzi, E. corsica). E. kraussei apparently represents an intermediate stage (Buschinger et al. 1986, Buschinger 1989) with usually small numbers of workers that nevertheless are able to conduct slave raids under very favorable laboratory conditions. Local populations of $E$. kraussei vary considerably. Thus, the population of Calabria (formerly $E$. foreli), and one from northern Spain, had means of 6.6 and 10.5 workers per colony, whereas a population from southern France, which had been described under the name E. vandeli, had no workers at all in 17 field nests, but produced 1 and 4, respectively, in two out of five laboratory-reared colonies (Buschinger et al. 1986). The E. kraussei of Crete, therefore, might represent a population in which the final instar, complete absence of workers, has been achieved within this species, as was predicted by Buschin- 
ger et al. (1986). Buschinger (1989) points out that the populations of $E$. kraussei and several other $E$. species are strictly isolated from each other, even if not situated on islands, because the young sexuals mate in the mother nests, and the females afterwards spread on foot only. Thus gene flow is interrupted, and the high variability of worker numbers is retained because the presumably adaptive genes for worker reduction cannot spread over all the range of the species.

The production of Epimyrma sexual offspring (Table 1) was comparatively low, even in the colonies no. 1, 5, 6 and 8, with reasonably high numbers of host workers. In seven colonies producing $E$.-sexuals a rate of $0.27 E$.-females per host worker was reared, whereas in a population from northern Italy this rate was 0.49 , from Calabria 0.47 , and in the nearly workerless population from southern France it was 0.62 (from Buschinger et al. 1986).

The numerical sex ratio in $E$. kraussei from Crete, 0.14 males/females, corresponds to that in other populations (N-Italy: 0.21 ; Calabria: 0.11; S-France: 0.15 ). The high female bias, as in the other nest-mating Epimyrma species, is certainly an adaptive consequence of inbreeding (Hamilton 1967).

In conclusion, Epimyrma kraussei from Crete in most of its features fits well to the general characteristics of the species, and with its workerlessness it completes our knowledge of the variable worker numbers found in different populations.

\section{SUMMARY}

Epimyrma kraussei, a "degenerate slave-maker" is recorded from Crete. It represents the first socially parasitic ant of this island. The host species is Leptothorax recedens, as in all other populations of E. kraussei. Apparently in this population the worker caste of the parasite is absent, whereas all other known populations have at least a few Epimyrma workers.

\section{ACKNOWLEDGMENT}

I am grateful to Dr. A. Legakis of the University of Crete, Iraklion, for a list of the ants hitherto recorded from Crete. 


\section{REFERENCES}

Agosti, D., And C. A. Collingwood.

1987. A provisional list of the Balkan ants (Hym. Formicidae) with a key to the worker caste. II. Key to the worker caste, including the European species without the Iberian. Mitt. Schweiz. Entomol. Ges. 60, 261-293.

BERNARD, F.

1955. Morphologie et comportement des fourmis lestobiotiques du genre Epixenus Emery. Ins. Soc. 2, 273-283.

Brown, W. L., JR., AND E. O. WiLson.

1957. A new parasitic ant of the genus Monomorium from Alabama, with a consideration of the status of genus Epixenus Emery. Ent. News 68, 239-246.

BUSCHINGER, A.

1989. Evolution, speciation, and inbreeding in the parasitic ant genus Epimyrma (Hymenoptera, Formicidae). J. Evol. Biol. (in press).

Buschinger, A. Fischer, K., Guthy, H.-P., JeSSEN, K., AND U. Winter.

1986. Biosystematic revision of Epimyrma kraussei, E. vandeli, and E. foreli (Hymenoptera: Formicidae). Psyche 93, 253-276.

Buschinger, A., AND J. HeInze.

1988. Practical tube nests for transportation and mailing of live ant colonies. Ins. Soc. 35, 206-208.

Buschinger, A., Jessen, K., AND H. Cagniant.

1989. The life history of Epimyrma algeriana, a slave-making ant with facultative polygyny (Hymenoptera, Formicidae). (in prep).

BUSCHINGER, A., AND U. Winter.

1985. Life history and male morphology of the workerless parasitic ant Epimyrma corsica (Hymenoptera: Formicidae). Entomol. Gener. 10, 65-75.

Douwes, P., Jessen, K., AND A. Buschinger.

1988. Epimyrma adlerzi sp.n. (Hymenoptera: Formicidae) from Greece: morphology and life history. Ent. scand. 19, 239-249.

ETTERSHANK, G.

1966. A generic revision of the world Myrmicinae related to Solenopsis and Pheidologeton (Hymenoptera: Formicidae). Aust. J. Zool. 14, 73-171.

Hamilton, W. D.

1967. Extraordinary sex ratios. Science 156, 477-488.

LegaKis, A.

1987. Aspects of zoogeography of the ants of Crete. In: Chemistry and Biology of Social Insects, Eder, J. and H. Rembold, eds., München, p. 77.

ToHmE, H., AND G. ToнmE.

1979. Le genre Epixenus Emery (Hymenoptera, Formicidae, Myrmicinae) et ses principaux représentants au Liban et en Syrie. Bull. Mus. natn. Hist. nat., Paris, $4^{\mathrm{e}}$ sér. 1 , sect, A, 1087-1108. 

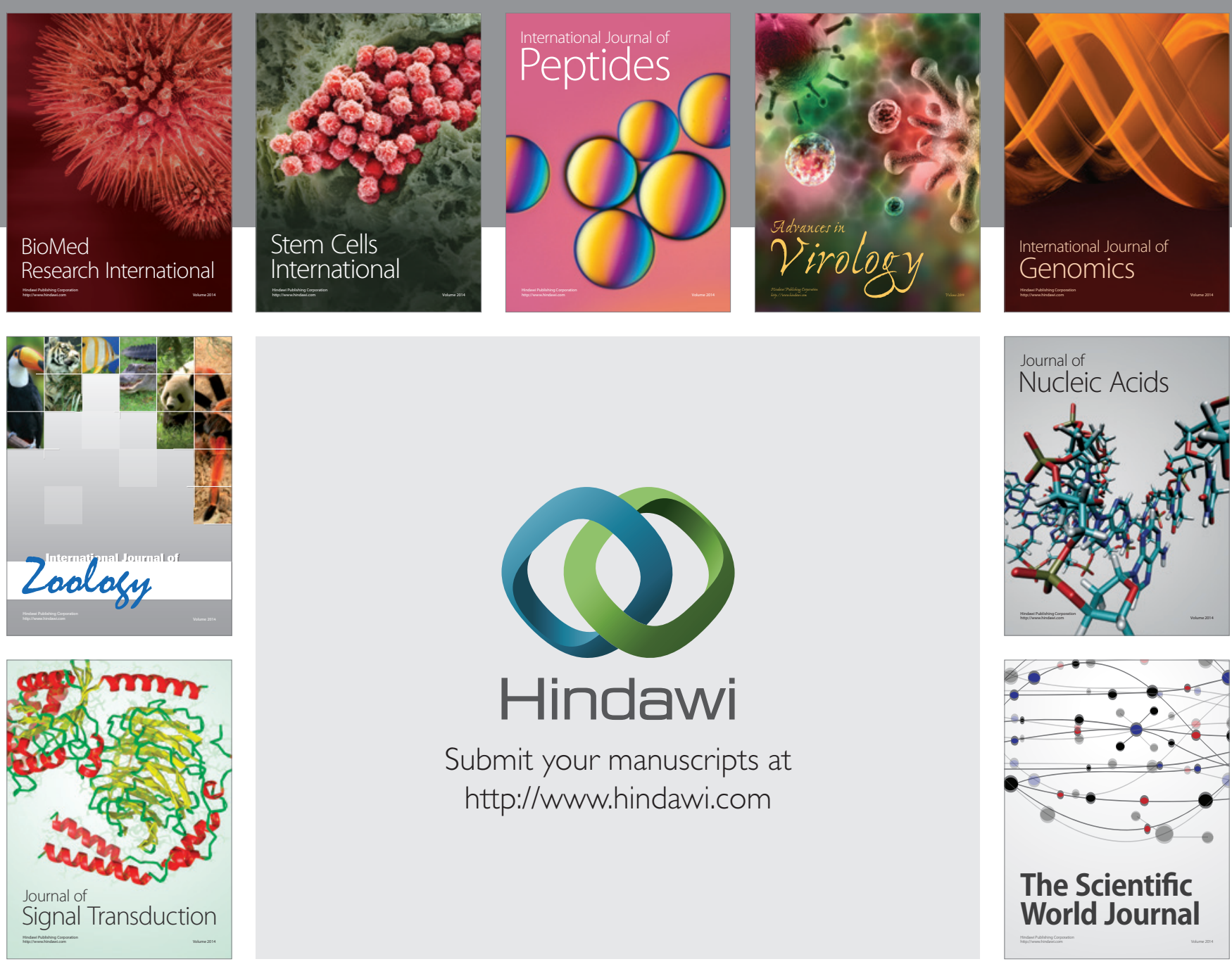

Submit your manuscripts at

http://www.hindawi.com
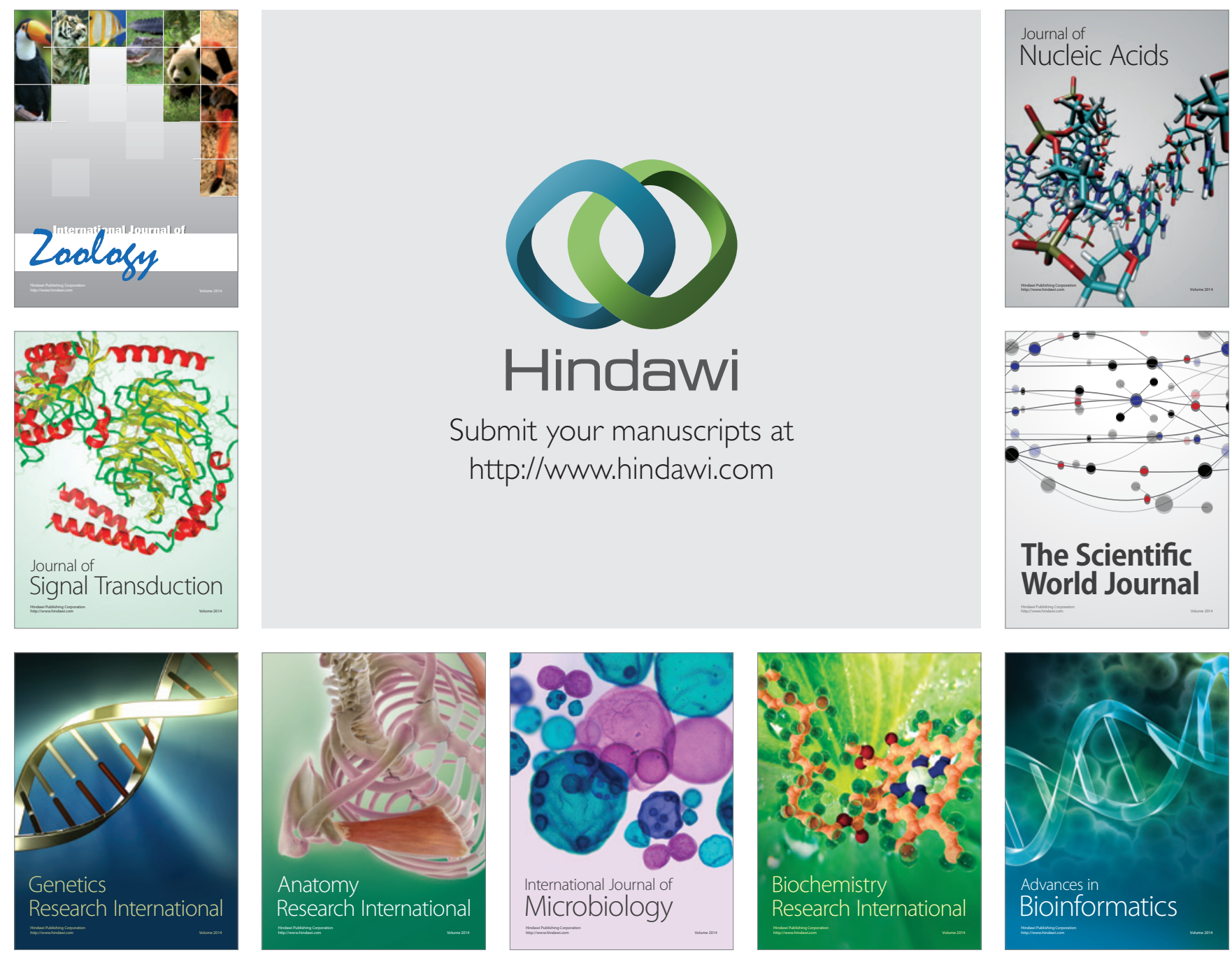

The Scientific World Journal
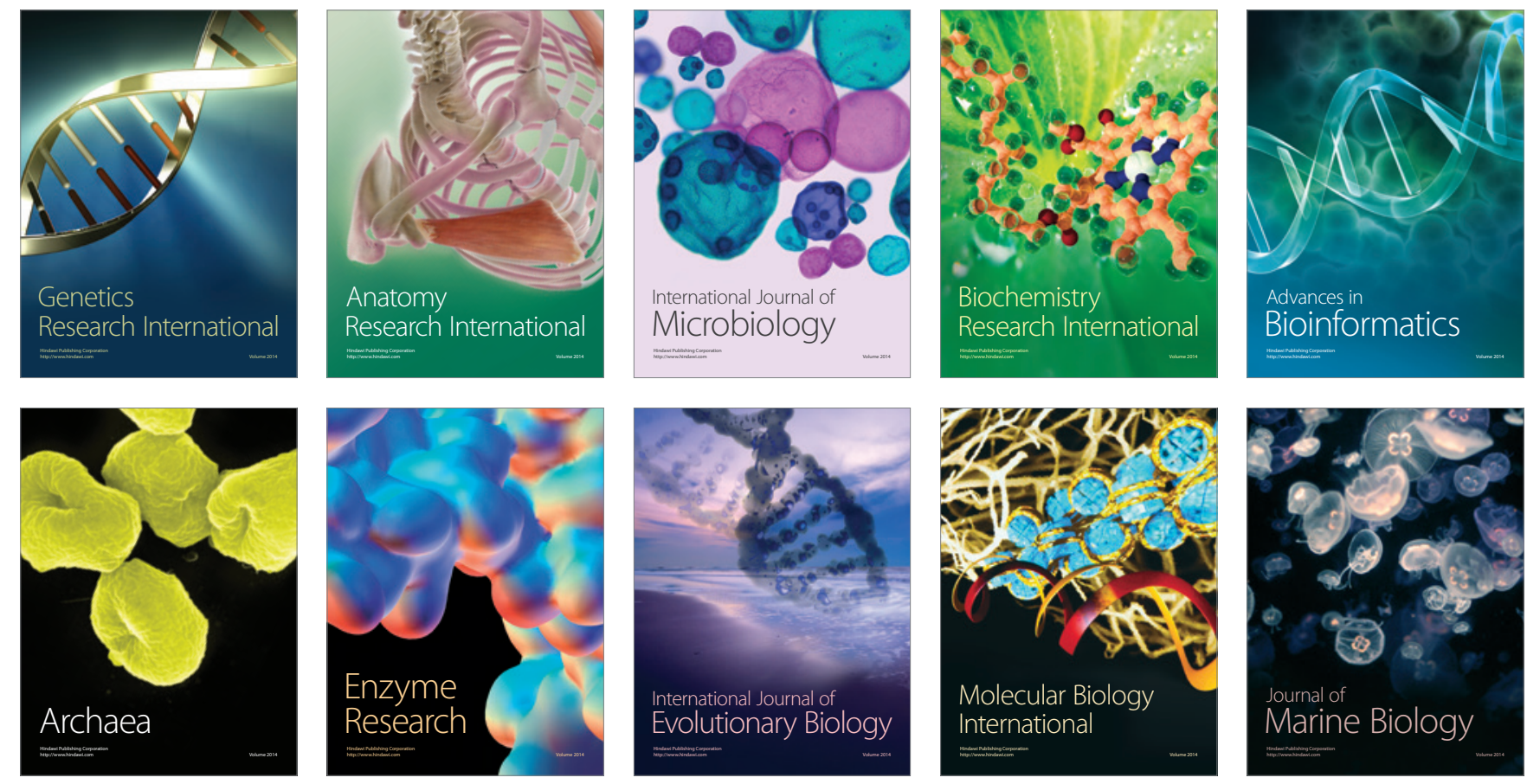